\title{
柏崎刈羽原子力発電所サービスホールの鉛直アレイ強震記録 から推定した地盤の非線形性状と基盤露頭波 \\ SOIL NONLINEARITY AND BEDROCK STRONG MOTIONS ESTIMATED FROM \\ DOWNHOLE ARRAY RECORDS AT KASHIWAZAKI-KARIWA NUCLEAR POWER PLANT DURING THE 2007 NIIGATA-KEN CHUETSU-OKI
}

\author{
時 松 孝 次 ${ }^{*}$, 新井 洋 ${ }^{* *}$, 㝨和 健太郎*** \\ Kohii TOKIMATSU, Hiroshi ARAI and Kentaro MINOWA
}

\begin{abstract}
Nonlinear soil properties as well as bedrock outcrop strong motions are back-calculated using 4-depth downhole strong motions recorded at the Kashiwazaki-Kariwa nuclear power plant during the 2007 Niigata-ken Chuetsu-oki earthquake. Adopted in the inverse analysis are genetic algorithms (GA) combined with a 1-D equivalent-linear response analysis in which strain-dependent damping ratios are assumed in the frequency domain. The inversion results show that the surface layer down to a depth of $70 \mathrm{~m}$ exhibited strong nonlinear behavior with a shear modulus ratio down to about 0.01 and a damping ratio up to about $35 \%$.
\end{abstract}

Keywords: the 2007 Niigata-ken Chuetsu-oki earthquake, downhole array record, equivalent S-wave velocity, strain-dependent damping ratio, bedrock strong motion, genetic algorithm 2007 年新潟県中越沖地震, 鉛直アレイ強震記録, $\mathrm{S}$ 波速度, 減衰定数, 基盤露頭波, 遺伝的アルゴリズム

\section{1. 序論}

2007 年 7 月 16 日に発生した新潟県中越沖地震（気象庁マグニチュ ード $\left.\mathrm{M}_{\mathrm{J}}=6.8\right)^{1)}$ では，震源域またはその近傍に位置する柏崎市や刈羽 村などで，地盤や建物等に多大な被害が生じた。その際，震央距離 16 $\mathrm{km}$ に位置する東京電力柏崎刈羽原子力発電所サービスホール(以下， サービスホール）では，地盤内 4 深度の鉛直アレイ強震記録が得られ た ${ }^{2), 3)}$. 得られたアレイ強震記録は, 大地震時の震源域内のもので, しかも，表層付近から深度 $250 \mathrm{~m}$ までの砂層および泥岩層内のものを 含み, 激震時におけるこれらの地盤の地震時挙動（非線形性状）を把 握する上で, また, この地域の基盤入力地震動を評価する上で, 極め て希有かつ貴重な資料と考えられる.

鈆直アレイ強震記録を用いて地盤の地震時挙動を把握する試みは, 太田 ${ }^{4)}$ の先駆的研究以来, 数多く行われている. 太田 $\left.{ }^{4}\right)$ は, $\mathrm{S}$ 波の鉛直 下方入射の仮定と 1 次元重複反射理論（例えば SHAKE などに代表さ れる等価線形解析） ${ }^{5}$ に基づいて，地表と地中の観測波形のフーリエ スペクトル比の逆解析から，地盤内各層の等価 $\mathrm{S}$ 波速度と等価減衰定 数の分布を同定している.

\footnotetext{
* 東京工業大学大学院理工学研究科建築学専攻 教授 $\cdot$ 工博

** 建築研究所構造研究グループ 主任研究員・博士 (工学)

*** 東京工業大学大学院理工学研究科建築学専攻 大学院生
}

小林ら ${ }^{6}$ は，地盤の減衰が，せん断による材料（履歴）減衰と散乱 減衰からなり, 前者は $\mathrm{S}$ 波速度に, 後者は周波数に依存すると仮定し た 1 次元重複反射理論に基づいて, 地盤物性の逆解析を行っている. 佐藤 7’は, 減衰の周波数依存性を考慮して, $\mathrm{S}$ 波の斜め入射による影 響について検討している。 しかし，いずれの研究も，減衰が微小ひず みレベルでの散乱減衰に支配されることを前提とし， せん断ひずみの 大きさに依存する履歴減衰が卓越すると考えられる強震動に適用する ことができない．

Chang $ら^{8)}$, 佐藤ら ${ }^{9}$ は, 減衰が履歴減衰に支配されることを前提と した等価線形解析に基づいて, 地盤減衰のせん断ひずみ依存性を同定 している.しかし，これらの手法を直接，サービスホールの強震記録 に適用することは難しいと考えられる。これは，これらの手法で用い られている等価線形解析を,大ひずタレベルの地震記録に適用すると, 高周波 (短周期) 成分の応答が過減衰となることが, 以前から指摘さ れているためである ${ }^{10)}$.

杉戸ら ${ }^{10}$ は, 上記の問題を解決するため, 各周波数の減衰定数が, せん断ひずみの時刻歴のフーリエ振幅に依存すると仮定した 1 次元等 Prof., Dept. of Architecture and Building Engineering, Graduate School of Science and Engineering, Tokyo Institute of Technology, Dr. Eng.

Senior Research Engineer, Dept. of Structural Engineering, Building Research Institute, Dr. Eng.

Graduate Student, Dept. of Architecture and Building Engineering, Graduate School of Science and Engineering, Tokyo Institute of Technology 
価線形解析を提案している。この手法は，順解析では既に多くの実績

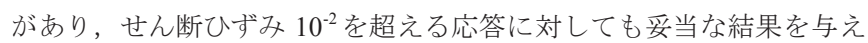
ている事例 ${ }^{11)}$ あることから，大ひずみレベルのアレイ強震記録から 地盤物性を評価寸る逆解析に容易に適用可能と考えられる.

以上の背景から，本論文では，各周波数の減衰定数が，せん断ひず みの時刻歴のフーリエ振幅に依存すると仮定した ${ }^{10)} 1$ 次元重複反射理 論に基づく逆解析により, サービスホールの鉛直アレイ強震記録から， 2007 年新潟県中越沖地震の本震および余震における地盤内の等価 $\mathrm{S}$ 波 速度と減衰定数のひずみ依存性（以下， $h-\gamma$ 関係）を推定する。 また， 解析から得られた深度 $250 \mathrm{~m}$ の基盤露頭波の特性について考察する.

\section{2. 鉛直アレイ観測点の地盤と強震記録}

サービスホールは，柏崎刈羽原子力発電所メインゲートの東側に位 置している (図 1） ${ }^{2)}$. サービスホールの深度 $250 \mathrm{~m}$ までの地盤の $\mathrm{S}$ 波

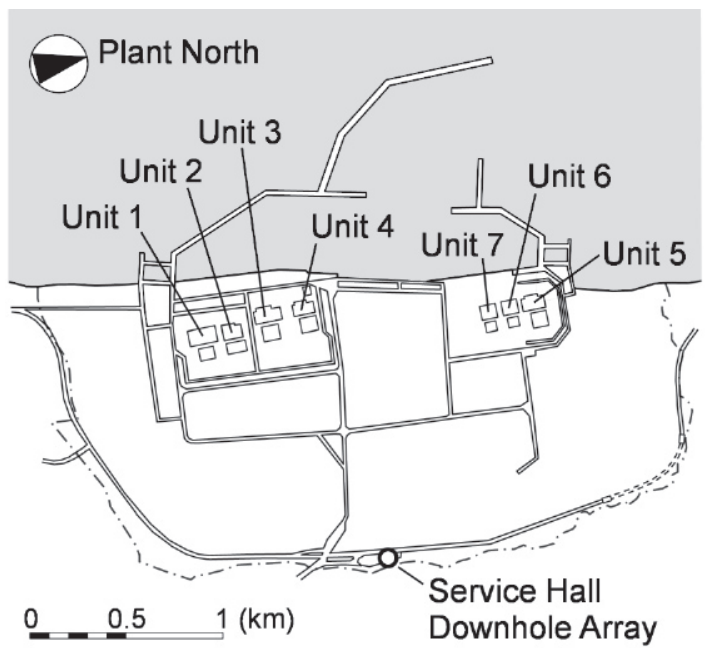

図 1 柏崎㺫羽原子力発電所および同サービスホール 鈶直アレイの位置 ${ }^{2)}$
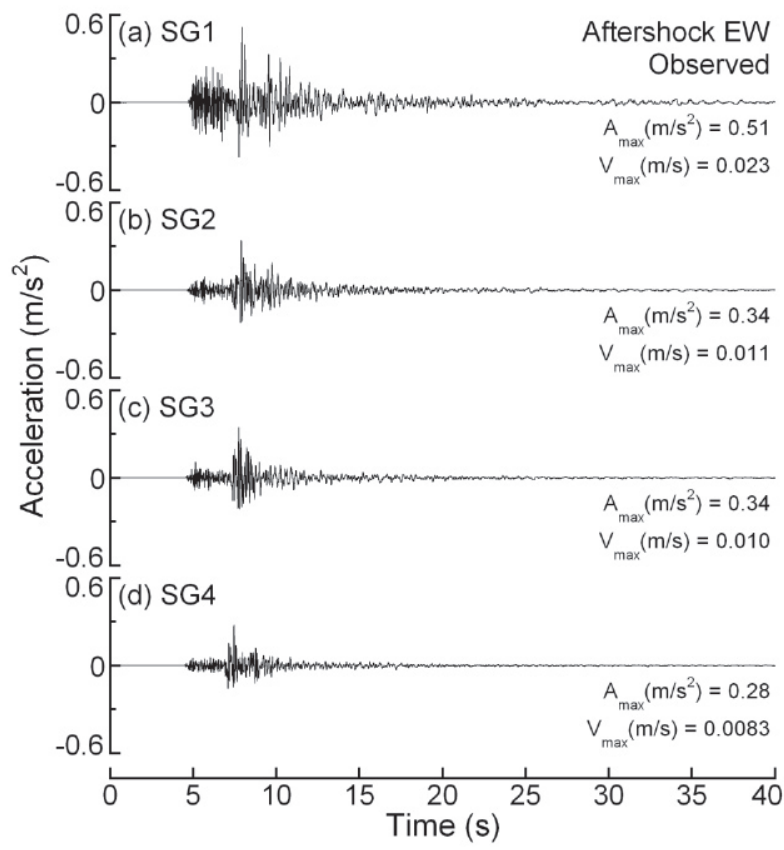

図 3 サービスホール鉛直アレイで得られた加速度時刻歴波形 (7月 16 日 21 時 08 分の余震, EW 成分) ${ }^{3)}$
速度構造と地質構造および地震計の埋設深度を図 $2^{2}$ に示す.この地点 の標高は $67.5 \mathrm{~m}$ で, 発電所 1-4, 5-7 号機のそれ (5.3m および $12.3 \mathrm{~m})$ と比べて, $62.2 \mathrm{~m}$ および $55.2 \mathrm{~m}$ 高くなっている. そのため, 発電所 1-7 号機の表層地盤にはほとんど存在しない新期砂層と番神砂層が，安田 層と西山層（泥岩）の上部を覆っている，文献 2)によると，地盤の $\mathrm{S}$ 波速度は, 新期砂層および番神砂層で 310-350m/s, 安田層で $350 \mathrm{~m} / \mathrm{s}$, 西 山層で $500-640 \mathrm{~m} / \mathrm{s}$ と, 深くなるにつれて大きくなっている. 地震計は, 深度 $2.4,50.8,99.4,250 \mathrm{~m}$ の 4 深度（以下，SG1-SG4）に，それぞれ 3 成分（鉛直および水平 $\mathrm{EW}, \mathrm{NS}$ 成分）埋設されている，ただし，水平 EW，NS の方位は，プラント建屋の向きに合わせてあり，それぞれ真 東および真北から時計回りに約 19 度回転している. なお，本震後，䇄 ービスホールの建物周辺や観測井（特に SG1）周辺の地盤は，相対的 に $15 \mathrm{~cm}$ 程度沈下し，表層地盤が極めて大きなひずみを受けたことを 示唆している．なお，付近に噴砂などは確認できなかった．

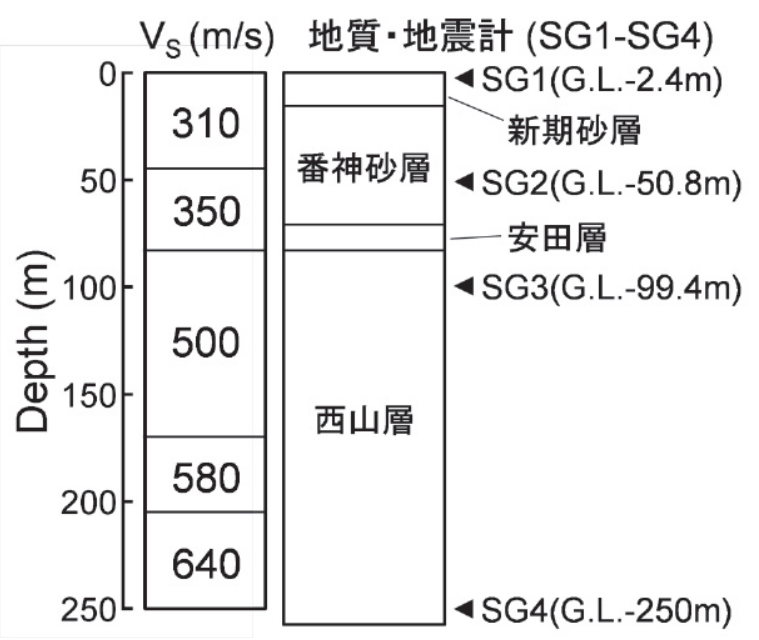

図 2 サービスホール鉛直アレイ地点の $\mathrm{S}$ 波速度構造, 地質構造, 地震計埋設深度 ${ }^{2)}$
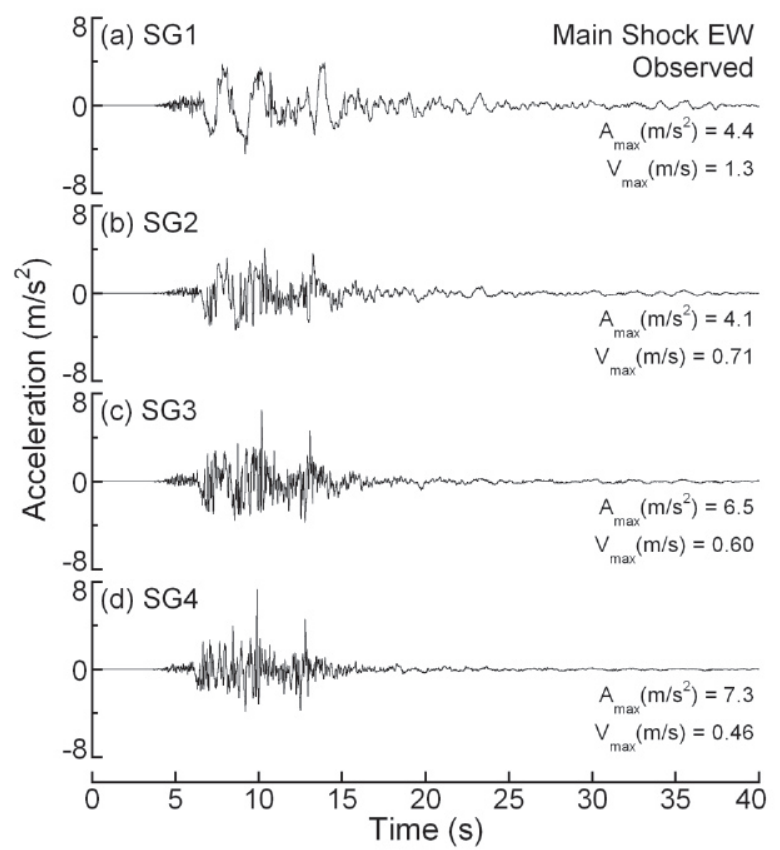

図 4 サービスホール鉛直アレイで得られた加速度時刻歴波形 (7月 16 日 10 時 13 分の本震, $\mathrm{EW}$ 成分) ${ }^{3)}$ 
本論文では，公開されている鉛直アレイ強震記録のうち，7月 16 日 10 時 13 分の本震および同 21 時 08 分の余震 $\left(\mathrm{M}_{\mathrm{J}}=4.4\right.$, 震源深さ $20 \mathrm{~km}$, 震央距離 $10 \mathrm{~km})^{3)}$ について, その卓越方向となる $\mathrm{EW}$ 成分を検討対象 とする. 図 3,4 に, 余震および本震時に観測された 4 深度の水平 $\mathrm{EW}$ 成分の加速度時刻歴波形 ${ }^{3)}$ 示す。図には，各深度の観測波形の最大 加速度と最大速度の值も示す. 最大速度は, 加速度波形の 1 自由度系 (固有周期 20 秒, 減衰定数 0.707) の相対速度応答 ${ }^{12}$ から求めた. 余 震（図 3）では，最大加速度・最大速度とも地表に向かって増大寸る 傾向が認められる。一方, 本震（図 4）では, 最大速度は地表に向か って増大しているが，最大加速度は地表に向かって減少している.

図 5,6 に, 各深度の $\mathrm{EW}$ 成分の観測波のフーリエスペクトル比を, 余震と本震で比較して, 黒細線で示寸.スペクトルはFFTにより求め, バンド幅 $0.2 \mathrm{~Hz}$ の Parzen Window で平滑化した後，除算している．図 5 から, 余震では, 周期 0.1-2 秒に見られるスペクトルピークは, いず れも 5 程度以上で鋭くなっている。，一方，本震（図 6）では，周期 1 秒以上のスペクトルピークは余震と同様に顕著である。しかし，深度 $100 \mathrm{~m}$ 以浅間のスペクトル比（SG1/SG2, SG1/SG3, SG2/SG3）は，いず れも, 余震に比べ, 1-2 秒のピーク周期が長くなり, そのピーク值が 3 程度と小さくなっている．また，本震のいずれのスペクトル比におい ても, 1 秒以下の短周期領域に, 顕著なスペクトルピークが見られず, スペクトルの值は概ね 1 またはそれ以下となっている.

以上のような, 余震と本震における地震動の深さ方向の増減傾向 (図
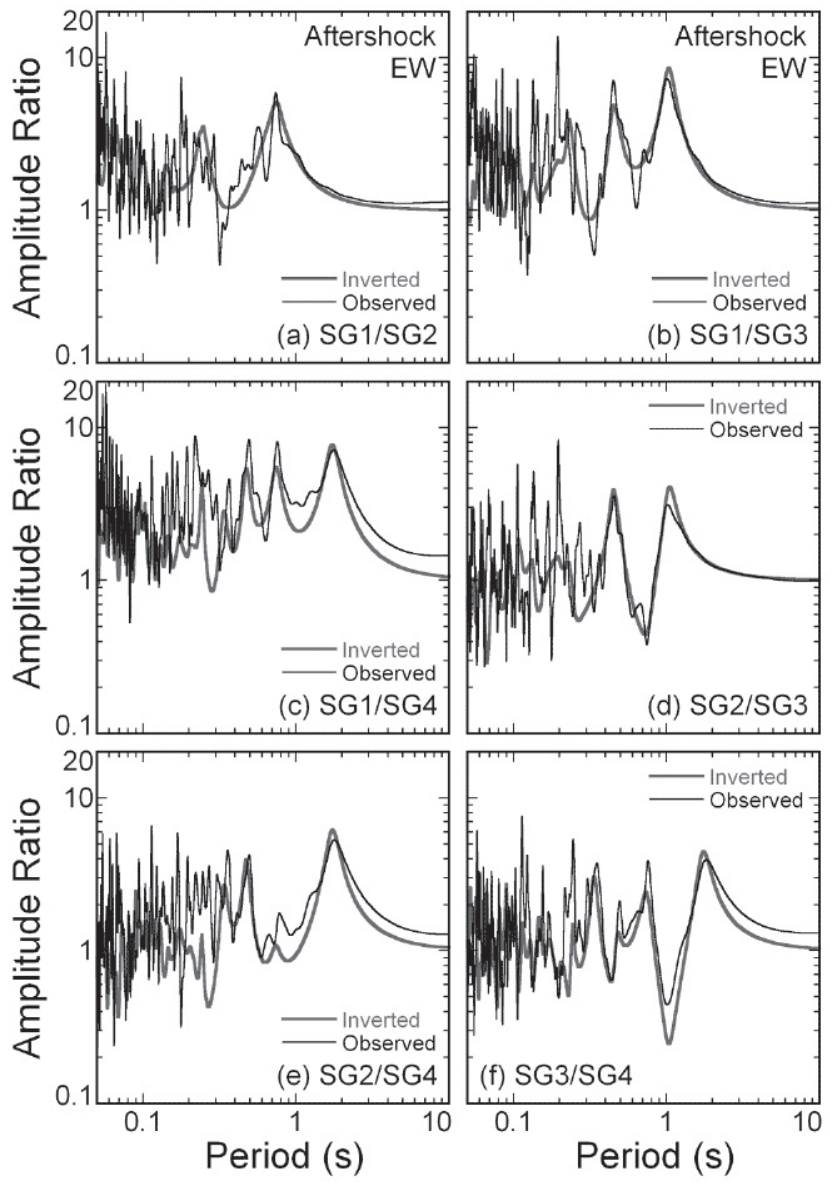

図 5 地震計埋設深度間の観測スペクトル比（黒細線）と逆解析 による理論スペクトル比（灰太線）（余震 EW 成分）
$3,4)$ とスペクトル比性状の違い（図 5,6）は，深度 50-100m 程度以浅 の地盤のいずれかの層が本震時に非線形化した可能性を示唆している。

\section{3. 遺伝的アルゴリズムによる地盤の S 波速度と減衰定数の推定方法}

本論文では，各周波数の減衰定数が，せん断ひずみの時刻歴のフー リエ振幅に依存寸ると仮定した ${ }^{10)} 1$ 次元重複反射理論に，大局的探索 能力が高く, ロバス卜性・安定性に優れた遺伝的アルゴリズム (GA) を適用した逆解析により，地盤物性を同定する。

\section{1 地盤の等価線形応答解析と必要な地盤物性}

地盤が $\mathrm{N}$ 層から成るものとし, 強震記録が異なる I 深度（層境界） で得られているものとする. 最下層は半無限, 各層は粘弾性体とし, $\mathrm{S}$ 波の鉛直下方入射を仮定し，各層の等価物性值を用いた 1 次元重複 反射理論に基づく線形解析（1 次元等価線形解析） ${ }^{5)}$ により, 観測され た各深度間のスペクトル比を説明できるものとする．この地盤の地震 応答解析に必要な各層の物性值は, 層厚 $\mathrm{H}$, 密度 $\rho$, 等価 $\mathrm{S}$ 波速度 $\mathrm{V}_{\mathrm{SE}}$, 減衰定数 $\mathrm{h}$ である。このうち，層厚 $\mathrm{H}$ と密度 $\rho$ は既知，等価 $\mathrm{S}$ 波速度 $\mathrm{V}_{\mathrm{SE}}$ および減衰定数 $\mathrm{h}$ は未知とし, $\mathrm{V}_{\mathrm{SE}}$ は一意に, h は, Hardin-Drnevich $(\mathrm{HD})$ モデル ${ }^{13}$ およよび杉戸ら ${ }^{109}$ の方法を参考に, 次式により与えられる ものとする.

$$
\begin{aligned}
& \mathrm{h}= \mathrm{h}\left(\gamma_{\mathrm{eff}}(f)\right)=\mathrm{h}_{\text {min }}{ }^{*}+\left(\mathrm{h}_{\text {max }}{ }_{\text {max }}-\mathrm{h}_{\text {min }}{ }^{*}\right)\left(\gamma_{\text {eff }}(f) / \gamma^{*}{ }_{\text {ref }}\right) /\left(1+\gamma_{\text {eff }}(f) / \gamma_{\text {ref }}{ }^{*}\right) \\
& \gamma_{\text {eff }}(f)=0.8 \gamma_{\text {max }} \cdot \Gamma(f)
\end{aligned}
$$
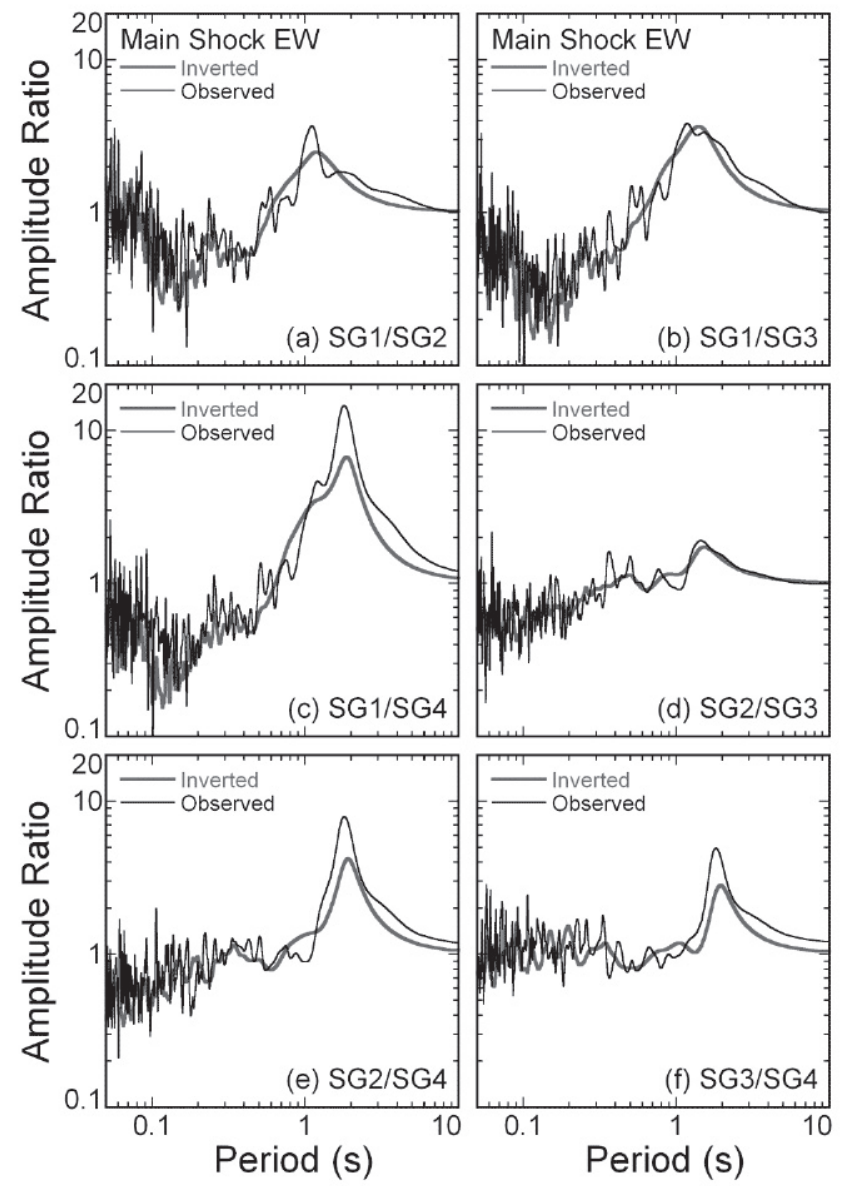

図 6 地震計埋設深度間の観測スペクトル比（黒細線）と逆解析 による理論スペクトル比（灰太線）（本震 EW 成分） 
ここに, $f$ は周波数, $\mathrm{h}_{\text {min }}{ }^{*}, \mathrm{~h}_{\text {max }}{ }^{*}$ は各層の最小および最大の減衰定数, $\gamma_{\text {ref }}^{*}, \gamma_{\text {max }}, \gamma_{\text {eff }}(f), \Gamma(f)$ は, 各層の規準せん断ひずみ, 最大せん断ひずみ, 各周波数に対する有効せん断ひずみ，せん断ひずみの基準化フーリエ スペクトル(最大值 1)である.このうち， $\gamma_{\max }, \gamma_{\text {eff }}(f), \Gamma(f)$ は，杉戸ら ${ }^{10)}$ の方法と同様, $\gamma_{\mathrm{eff} f}(f)$ の収斂計算（繰り返し応答解析）を行えば求めら れるため, 各層に対して独立の未知パラメータは, $\mathrm{V}_{\mathrm{SE}}, \mathrm{h}_{\text {min }}{ }_{\text {min }}, \mathrm{h}_{\text {max }}{ }^{*} \gamma_{\text {ref }}{ }^{*}$ の 4 つとなる. なお, 逆解析から推定される $\mathrm{h}^{*}{ }_{\text {min }}, \mathrm{h}^{{ }_{\text {max }}}, \gamma_{\text {ref }}{ }^{*}$ は, 有効 せん断ひずみ $\gamma_{\text {eff }}=0.8 \gamma_{\max }$ 以下の $\mathrm{h}-\gamma$ 関係が最適となるように求められ た值で, 実際の地盤材料の最大・最小值などと直接対応しない可能性 があるため, *をつけて区別している.

\section{2 逆解析の方法}

逆解析は，観測スペクトル比を説明できる最適な地盤パラメータを 探索することで, その評価関数 $F$ (misfit) を次式とすれば，これを最 小とする地盤パラメータを同定することとなる.

$$
F=\sum_{i=1}^{\mathrm{I}-1} \sum_{j=i+1}^{\mathrm{I}} \sum_{k=k_{\min }}^{k_{\max }} w_{k}^{2}\left(\log _{10} A_{\mathrm{m}, i j}\left(f_{k}\right)-\log _{10} A_{\mathrm{c}, i j}\left(f_{k}\right)\right)^{2}
$$

ここに, $A_{\mathrm{m}, i j}(f)$ および $A_{\mathrm{c}, i j}(f)$ は, 地震計埋設深度（全 I 個）のうち任意 の 2 深度 $i, j$ 間の観測および理論スペクトル比, $k_{\min }, k_{\max }$ は整数で, そ れぞれ $f_{\min } / \mathrm{T}, f_{\max } / \mathrm{T}, f_{\min }, f_{\text {max }}$ は対象周波数の最小值と最大值, $\mathrm{T}$ は加速 度記録の継続時間, $w_{k}$ は重みで $1 / f_{k}$ である. なお, 理論スペクトル比 の算定では, 観測スペクトル比（図 5,6 ） と同等の平滑化処理を行う.

逆解析に用いた遺伝的アルゴリズム (GA) は, Goldberg ${ }^{14)}$, 山中・ 石田 ${ }^{15)}$ などを参考に, 突然変異率を高めに設定した単純 $\mathrm{GA}^{(4)}$ にエリ

一ト選択を加える方法で, その概要は以下のとおりである.

まず, 地盤各層の未知パラメータを J ビット (Gray Code $)^{14)}$ に離散
表 1 逆解析における地盤各層の最小・最大減衰定数および 規準せん断ひずみの探索範囲

\begin{tabular}{|c|c|}
\hline パラメータ & 探索範囲 \\
\hline 最小減衰定数 $\mathrm{h}_{\text {min }}{ }^{{ }^{*}}$ & $0 \sim 5(\%)$ \\
\hline 最大減衰定数 $\mathrm{h}_{\text {max }}{ }^{*}$ & $15 \sim 40(\%)$ \\
\hline 規準せん断ひすすみ $\gamma^{*}{ }_{\text {ref }}$ & $-4 \sim-2\left(\log _{10}{ }^{*}{ }^{*}{ }^{*}\right)$ \\
\hline
\end{tabular}

化し，乱数を用いて M 個の地盤モデル（集団）を作成する. 次に, 各 地盤モデル（個体）の適合度を(3)式の逆数をスケーリング ${ }^{14)} し た$ 值に より評価し, エリート選択, 親選択, 2 点交叉, 突然変異 ${ }^{14)}$ の操作を 行って, 次世代の集団を生成する. この評価・操作を $\mathrm{L}$ 世代繰り返し た時点で最も良い適合度を持つ地盤モデルを 1 回の試行での最適解と する. GA は確率的探索法の一種であるから, 乱数の初期值を変えて 複数回の試行を行い, 得られた最適解の分布を最終的な推定值とする. 3.3 サービスホール鉛直アレイ記録への適用

逆解析にあたり, サービスホール直下の地盤を, ボーリング調查や PS 検層結果, 地震計の埋設深度など ${ }^{2), 3)}$ を参考に, $\mathrm{N}=16$ 層に分割す る（図 7)。地震計埋設深度 SG1-SG4 は, 第 3, 9, 13, 16 層の上端に位 置している. 地盤各層の密度 $\rho$ は, 地質や土質など ${ }^{2), 33}$ から, 新期砂層, 番神砂層, 安田層, 西山層で, それぞれ $1.65,1.65-1.80,1.80,1.65-1.75$ $\mathrm{Mg} / \mathrm{m}^{3}$ と仮定する. 各層の未知パラメータ $\left(\mathrm{V}_{\mathrm{SE}}, \mathrm{h}_{\text {min }}{ }^{*}, \mathrm{~h}_{\text {max }}{ }^{*}, \gamma_{\text {ref }}^{*}\right)$ の探 索範囲は, PS 検層 ${ }^{2}$ や既往の室内動的試験結果など ${ }^{16), 17)}$ を参考に, 土 の值として工学的に有り得る範囲とし, さらに, 本震時の表層部での 顕著な剛性低下を考慮して, 図 7 および表 1 のように定める.

地盤各層のせん断ひずみおよび各層境界での加速度の時刻歴や最大 值などは, 余震・本震とも, 深度 $250 \mathrm{~m}(\mathrm{SG} 4)$ の観測加速度波形（EW

S-Wave Velocity $(\mathrm{m} / \mathrm{s})$ Max. Shear Strain S-Wave Velocity $(\mathrm{m} / \mathrm{s})$ Max. Shear Strain 地質·地震計

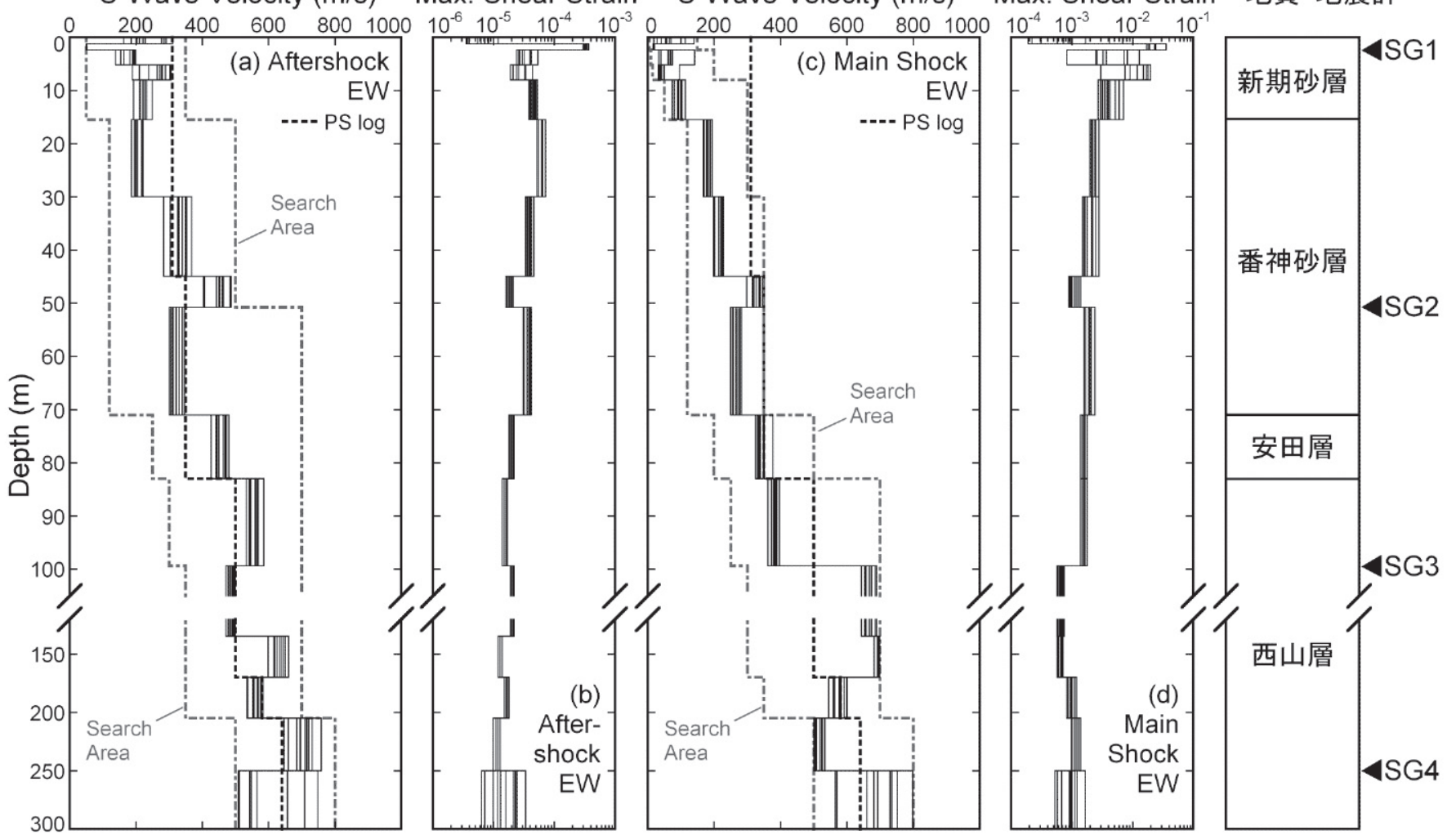

図 7 逆解析における地盤各層の等価 $\mathrm{S}$ 波速度の探索範囲および推定結果, 解析から得られた最大せん断ひずみ（余震・本震， $\mathrm{EW}$ 方向） 
成分)を $\mathrm{S}$ 波の within motion として用いた場合の応答解析結果を用い, $\mathrm{T}=81.92 \mathrm{~s}, f_{\min }=0.2 \mathrm{~Hz}, f_{\max }=25 \mathrm{~Hz}, \mathrm{I}=4$ として, ${ }_{\mathrm{I}} \mathrm{C}_{2}=\mathrm{I}(\mathrm{I}-1) / 2=6$ 組す心゙ てのスペクトル比を(3)式の評価に用いる。.また, GA では, J=8 ビッ 卜, $\mathrm{M}=200$ 個体, $\mathrm{L}=500$ 世代, 親選択はルーレット規則, 交叉率 $70 \%$, 突然変異率 $2 \%$ とし, 10 回の試行を行った.

\section{4. 逆解析から推定された地盤の等価 S 波速度と減衰定数}

図 5,6 の灰太線は, 余震・本震それぞれについて, GA 全 10 試行の うち misfit（(3)式）が最小となる最適解（地盤モデル）に対応する地 震計埋設 4 深度間の 6 組の理論スペクトル比である，理論值は，いず れのスペクトル比においても, 絶対值 - 周期特性とも, 観測值と良く 適合している. 特に, 本震時における, 深度 $100 \mathrm{~m}$ 以浅間の 1 秒以上 のスペクトル比（SG1/SG2，SG1/SG3,SG2/SG3）のピーク周期の伸び やピーク值の低下ならびに全スペクトル比における 1 秒以下の短周期 領域での顕著なスペクトルピークの消失なども良く再現している．ま た, $\mathrm{GA}$ 全 10 試行の最適解の misfit $の$ 変 動係数は, 余震・本震に対して $0.01,0.03$ であり,どの試行においても，理論と観 測のスペクトル比は図 5,6 と同程度に適 合することを確認している.このことは， 余震・本震とも，逆解析がある程度適切 に行われたことを示唆している.ただし， 本震では, SG4 を分母とする 3 スペクト ル比 (SG1/SG4, SG2/SG4, SG3/SG4) にお いて, 逆解析による 1 次ピークが過小評 価されている，その原因として，まず減 衰定数の仮定の問題が考えられる．例え ば，(1)式で定義した関数の自由度が少な いことによる影響などである。しかし， 観測スペクトルのピーク值が余震より本 震で大きいこと，また NS 方向ではその ような傾向はほとんど認められないこと から, 本震の $\mathrm{EW}$ 方向特有の問題, 例え ば, EW 方向の 2 次元的地形効果の影響 などの可能性も考えられる。

図 7 に，余震・本震に対して推定され た地盤各層の等価 $\mathrm{S}$ 波速度 $\mathrm{V}_{\mathrm{SE}}$ および最 大せん断ひずみ $\gamma_{\max }$ の分布を黒細線で示 す.また，図 8,9 に，新期砂層，番神砂 層，安田層，西山層からそれぞれ代表的 な 1-3 層（計 9 層）について，余震およ び本震に対して推定された最小・最大減

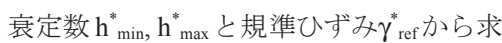
めた $\mathrm{h}-\gamma$ 関係（(1)式）の分布を示す．図 8,9 では, 解析で有効ひずみ $\gamma_{\mathrm{eff}}(f)$ の值が 得られた範囲のみを示している.

本論で用いた GA の場合，解のトレー ドオフが生じる可能性や，感度が低い解 が存在する可能性がある．現状でその可 能性を否定することは難しい。しかし，
得られた $\mathrm{V}_{\mathrm{SE}}, \gamma_{\mathrm{ref}}{ }_{\mathrm{ref}}$ の平均変動係数は $0.1,0.4$ 程度, $\mathrm{h}_{\text {min }}{ }^{*}, \mathrm{~h}^{*}{ }_{\text {max }}$ の平均標 準偏差は $0.008,0.04$ 程度と比較的小さく, また, 図 8,9 から, 本震に 対して求められた地盤各層の $\mathrm{h}-\gamma$ 関係は余震の結果を概社包含してお り, 比較的安定した解が得られていると判断される。ただし, 図 7 か ら, 余震・本震とも, 地盤モデルの最上層を含む 4 層程度および最下 層では，上方あるいは下方に地震記録が存在しないため，または，顕 著な非線形化のためか，他よりばらつきがやや大きい，また，余震よ り本震の方が大きな等価 S 波速度が推定されている層（例えば第 12 層）がある，その原因として，解析の仮定，評価関数の設定，地震記 録の $\mathrm{S} / \mathrm{N}$ 比，解のトレードオフなどの影響が考えられるが，その特定 は今後の課題としたい，なお，等価 $\mathrm{S}$ 波速度 $\mathrm{V}_{\mathrm{SE}}$ の探索範囲は，本震 時の剛性低下も考慮して決定したため，本震と余震で異なっている。 念のため, $\mathrm{V}_{\mathrm{SE}}$ の探索範囲を本震での探索範囲の最小值から余震での 探索範囲の最大值とした試行を余震・本震に対して行い，探索範囲に より，推定される $\mathrm{V}_{\mathrm{SE}}$ に差異がないことを確認している.
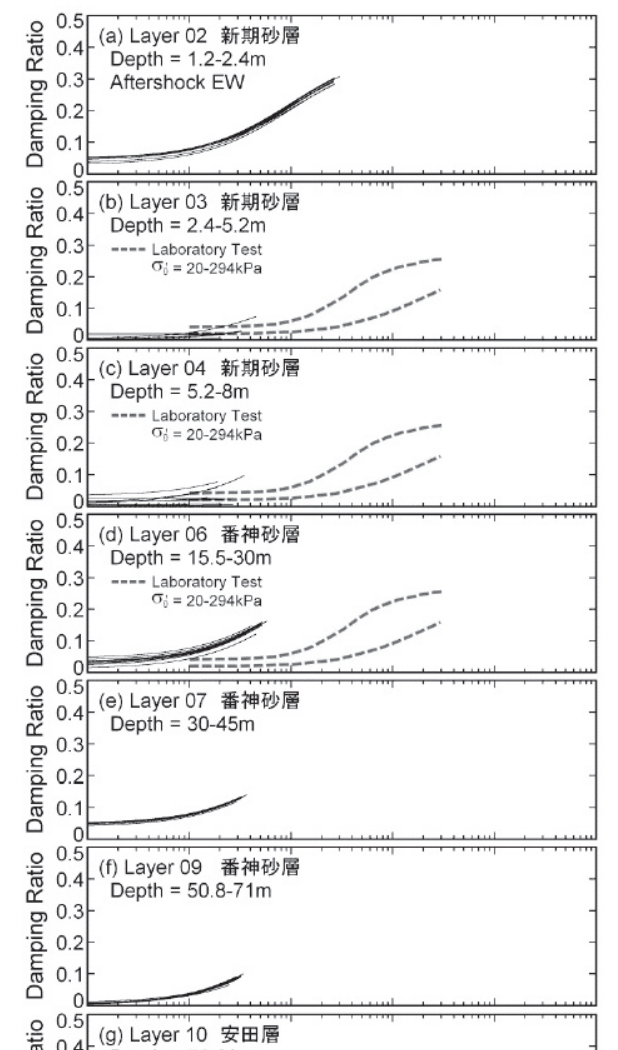

荧 $0.4-$ (g) Layer

다다. 0.3

宽 0.2

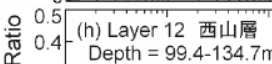

일 0.3

产 0.2

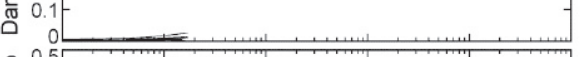

赵 0.5 (i) Layer 14 西山層

읻 0.3

है 0.2

हू

$10^{-6}$

$10^{-5}$

$10^{-4}-10^{-3}$

図 8 地盤各層で推定された減衰定数の せん断ひずみ依存性 (余震 EW 成分)

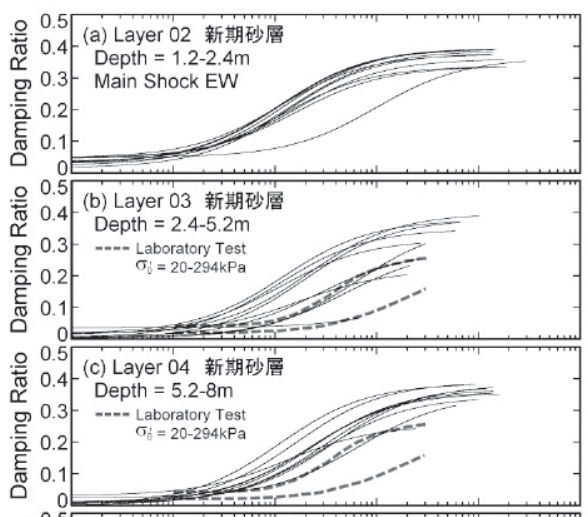

은 0.5 (d) Layer 06 番神砂層

व 0.4 Depth $=15.5-30 \mathrm{~m}$

$0.3---$ Laboratory Test
$\sigma_{j}^{\prime}=20-294 \mathrm{kP}$

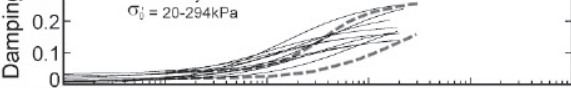

은 0.5 (e) Layer 07 番神砂層

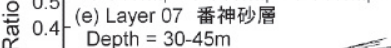

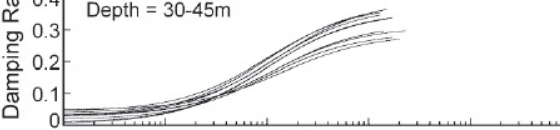

은 0.5 (f) Layer 09 番神砂層

葓 0.4 (f) Layer 09 番神砂

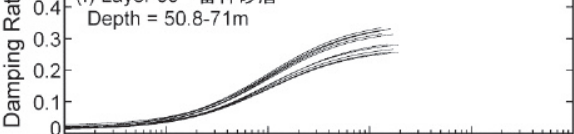

은 0.5 (g) Layer 10 安田層

(5) 0.4 Depth $=71-83 \mathrm{~m}$

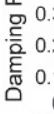

은 0.5 (h) Layer 12 西山層

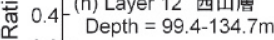

궁 0.3

高 0.

胥 0.1

은 0.5 (i) Layer 14 西山層

$\widetilde{1} 0.4$ Depth $=170-205 \mathrm{~m}$

일 0.3

들 0.2

品

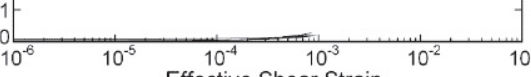

Effective Shear Strain

図 9 地盤各層で推定された減衰定数の せん断ひずみ依存性 (本震 EW 成分) 
図 7 より, 深度 $70 \mathrm{~m}$ 以深の層（安田層・西山層）の余震および本震 の最大せん断ひずみは，それぞれ $1 \times 10^{-5}-2 \times 10^{-5}$ 程度， $5 \times 10^{-4}-2 \times$ $10^{-3}$ 程度であるが，等価 $\mathrm{S}$ 波速度は，余震・本震で概敉同等であり， 地震前に実施された PS 検層結果（黒点線）とも概教整合している. また, 図 8,9 から, これらの層の余震・本震における最大減衰定数は $3 \%$ 程度以下および $5 \%$ 程度以下であり, 地震の大小による違いが少な い. 以上の結果は, 本震において, 深度 $70 \mathrm{~m}$ 以深の層の非線形化は顕 著でなかったことを示唆している.

一方, 図 7 から, 深度 $70 \mathrm{~m}$ 以浅の層（新期砂層・番神砂層）の本震 の最大せん断ひずみは $2 \times 10^{-3}-3 \times 10^{-2}$ 程度であり, 余震時の值 $(3 \times$ $10^{-5}-3 \times 10^{-4}$ 程度）より 100 倍程度大きい。 また, 本震における等価 $\mathrm{S}$ 波速度は, 余震における值や PS 検層結果に比心゙て小さく, その傾向 は浅い層ほど顕著である，なお，余震における等価 $\mathrm{S}$ 波速度は，深度 $30 \mathrm{~m}$ 以深ではPS 検層結果と概ね整合しているが, それ以浅では $200 \mathrm{~m} / \mathrm{s}$ と PS 検層結果の 0.7 倍程度となっている. その原因は不明であるが, 地盤各層の本震時の等価 $\mathrm{S}$ 波速度の $\mathrm{PS}$ 検層結果および余震時の等価 $\mathrm{S}$ 波速度に対する比（括弧内が余震の值に対するもの）は，番神砂層で 0.6-0.8（0.7-0.9）程度, 新期砂層で 0.1-0.3（0.1-0.4）程度であり, せ 儿断剛性比にして, 番神砂層で 0.4-0.6（0.5-0.8）程度, 新期砂層で 0.01-0.1（0.01-0.2）程度となる．これらの結果は，既往の砂試料の室 内動的試験結果（せん断ひずみ $10^{-3}$ でせん断剛性比 0.2-0.5 程度, せん 断ひずみ $10^{-2}$ でせん断剛性比 0.05-0.2 程度 ${ }^{16)}$, 17) と概ね調和的である.

図 8,9 から, これら砂層の最大減衰定数は, 上方に地震記録が存在 しない第 2 層を除いて，余震時には 5-10\%程度であるが，本震時には 20-35\%程度で, 本震時に大きなひずみを生じる層で大きな值となる傾

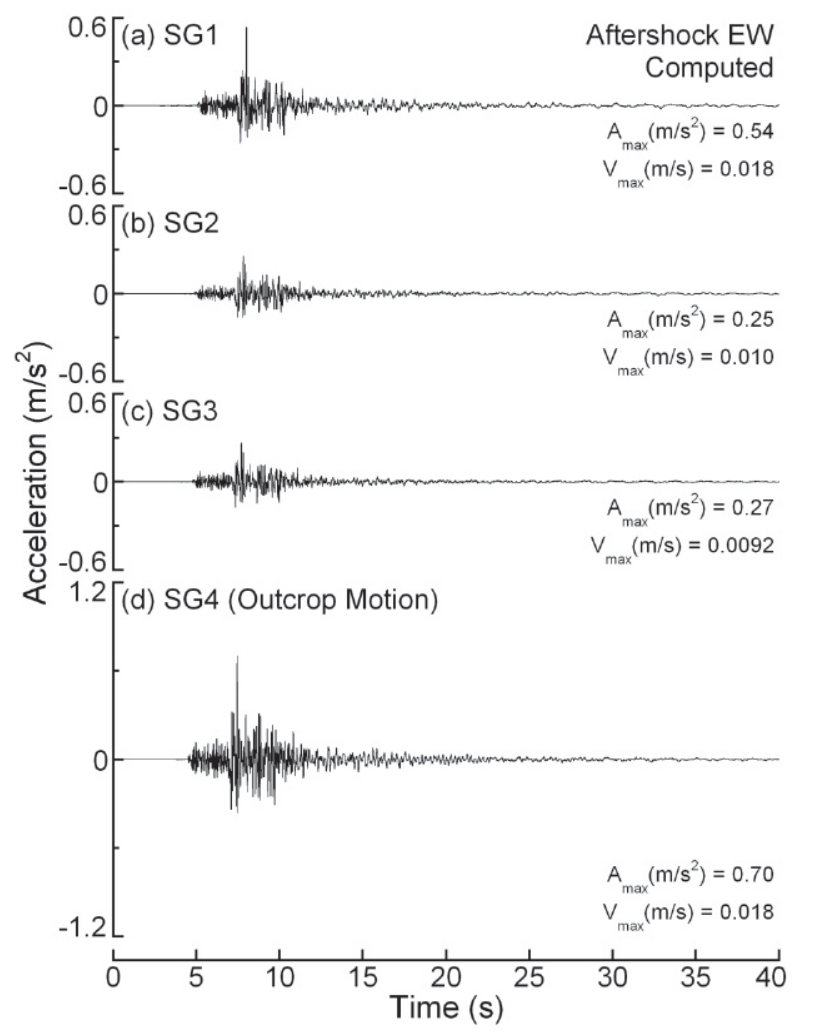

図 10 最適地盤モデルの応答解析から得られた SG1-SG4 の理論 加速度時刻歴波形（SG4 の夕基盤露頭波）（余震 $\mathrm{EW}$ 成分）
向があり，減衰のひずみ依存性が明瞭に認められる．図 8,9 の灰点線 は, 既往の砂試料の室内動的試験結果の範囲（深度 2-30m 程度） ${ }^{16), 17)}$ を示している. 同定された $\mathrm{h}-\gamma$ 関係は, 余震・本震時とも, 既往の室 内試験結果と概社調和的であるものの, やや大きめの值となっている.

図 7-9 に示寸地盤各層の等価 $\mathrm{S}$ 波速度および $\mathrm{h}-\gamma$ 関係は, それぞれ独 立に同定されたものである (3 章)。それにもかかわらず，同定された 等価 $\mathrm{S}$ 波速度（図 7) およびh- $\gamma$ 関係（図 8,9）から推察された各層の 非線形化の程度は，いずれも上述のとおり，既往の室内試験結果と定 性的には整合している. このことは, 推定結果の妥当性を支持する要 素の一つとも考えられ, 媣度 $70 \mathrm{~m}$ 以浅の砂層が, 本震時に顕著に非線 形化し, その程度は浅い層ほど顕著であったことを強く示唆している. なお, 減衰定数が既往の室内試験結果に比べて大きめに推定された原 因として, 1 次元波動理論の仮定（鉛直入射，水平成層），散乱減衰を 無視したことの影響, 室内実験と原位置の応力条件の相違などが考え られるが，その特定は今後の課題としたい.

\section{5. 観測波形のシミュレーションと基盤露頭波の特徵}

図 10,11 に，余震・本震それぞれについて， GA 全 10 試行のうち misfit が最小となる最適解（地盤モデル）を用いた地震応答解析から 得られた地震計埋設深度 SG1-SG4 の理論加速度時刻歴波形( EW 成分, SG4 の夕基盤露頭波）を示す，図には，各深度の理論波形の最大加速 度と最大速度の值も示している，本論文では，本震など顕著な非線形 現象が生じたと考えられる地震動に対して, 等価線形解析を実施して いるが, 図 3,4 との比較から, 余震・本震とも, その最大值は, 深度 $50.8 \mathrm{~m}$ の SG2 で観測值との適合度がやや悪いものの, その他の深度の

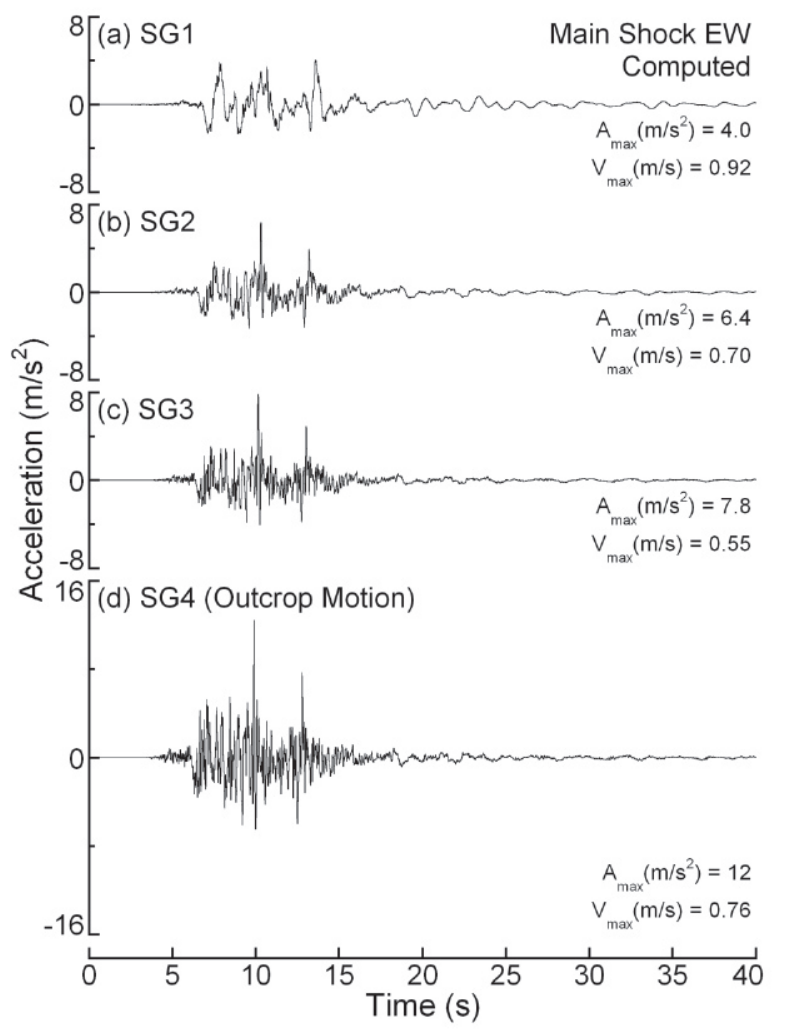

図 11 最適地盤モデルの応答解析から得られた SG1-SG4 の理論 加速度時刻歴波形（SG4 のみ基盤露頭波）（本震 $\mathrm{EW}$ 成分） 

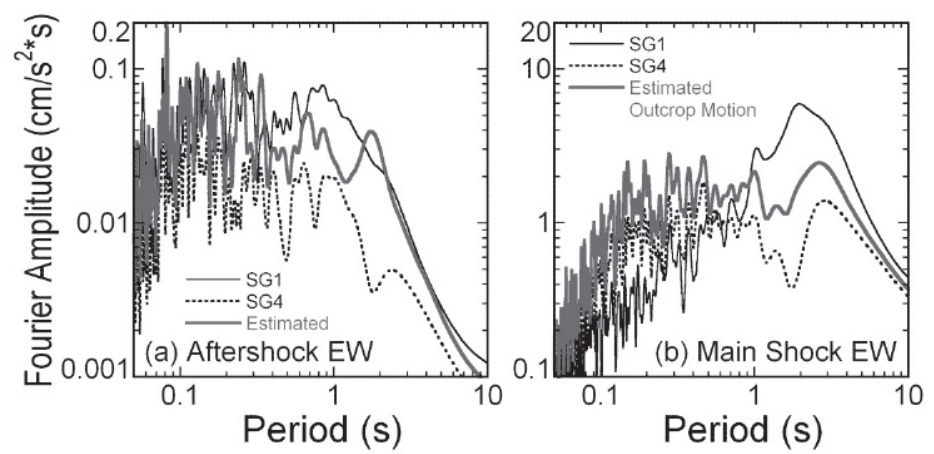

図 12 推定された SG4 の基盤露頭波と SG1, SG4 の観測記録の 加速度フーリエスペクトル (余震・本震, $\mathrm{EW}$ 成分)
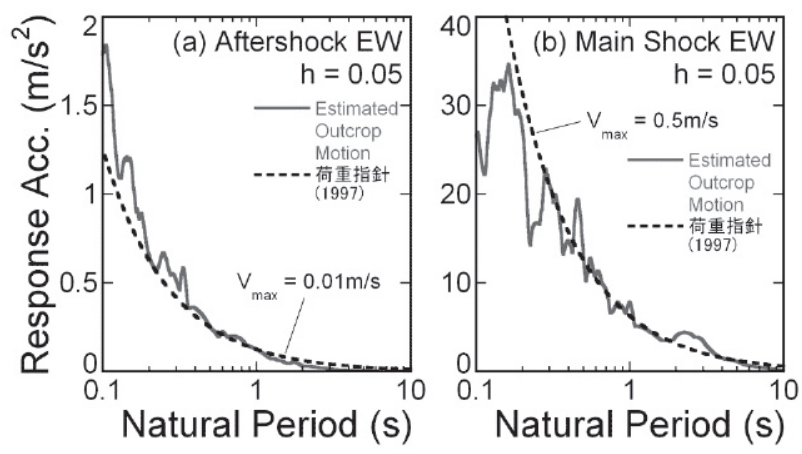

図 13 推定された SG4 の基盤露頭波の加速度応答スぺ クトル（減衰定数 $5 \%$, 余震・本震, $\mathrm{EW}$ 成分)

度, 対応する等価 $\mathrm{S}$ 波速度は 200-350m/s 程度, $500-700 \mathrm{~m} / \mathrm{s}$ 程度で ある. 推定された表層の等価 S 波速度は, PS 検層結果の 0.7-1 倍程 度であるが，それより深部の推定值は，PS 検層結果と調和的であ る. また, 推定された最大減衰定数は, 表層で $5-10 \%$ 程度, 深部で 3\%程度以下である.

3) 本震記録の逆解析から推定された最大せん断ひずみは, 深度 $70 \mathrm{~m}$ までの砂層で $2 \times 10^{-3}-3 \times 10^{-2}$ 程度, それ以深で $5 \times 10^{-4}-2 \times 10^{-3}$ 程 度, 対応する等価 $\mathrm{S}$ 波速度は $20-250 \mathrm{~m} / \mathrm{s}$ 程度, $400-700 \mathrm{~m} / \mathrm{s}$ 程度であ る. 表層 $\mathrm{S}$ 波速度は，余震記録の逆解析および PS 検層の結果のそ れぞれ 0.1-0.9, 0.1-0.8 倍程度（せん断剛性比で 0.01-0.8, 0.01-0.6 程 度）となっているが, それより梁部の推定值は, 余震に対する推定 結果ならびに PS 検層結果と調和的である，また，推定された減衰 定数は, 表層で $20-35 \%$ 程度, 深部で $5 \%$ 程度以下である.

4) 逆解析から求められたせん断岡性比と減衰定数のせん断ひずみ依 存性は, 減衰定数の絶対值を除いて, 既往の砂試料の室内動的試験 結果と概衩調和的である。

5) 以上から, 表層 $70 \mathrm{~m}$ 程度までの地盤が，本震時に大きく非線形化 したものと推察される.

6) 逆解析から推定された深度 $250 \mathrm{~m}$ での基盤露頭波は, 本震・余震と も, その加速度フーリエスペクトルの形状が, 周期 0.1 秒程度から 2-3 秒までの範囲で比較的平坦であり, 工学的基盤露頭波の特性を 有していると考えられる. また, 推定された本震の基盤露頭波の最 大加速度は $12 \mathrm{~m} / \mathrm{s}^{2}$, 最大速度は $0.8 \mathrm{~m} / \mathrm{s}$ 程度である.

\section{謝辞}

本論文では, 東京電力株式会社が公開した文献 2), 3)のデータを使用 した。また，現地調查は東京電力株式会社のご厚意により行った．記 して謝意を示す.

ら, 地盤内の等価 $\mathrm{S}$ 波速度および減衰定数のせん断ひずみ依存性 $(\mathrm{h}-\gamma$ 関係）を推定し，さらに得られた深度 $250 \mathrm{~m}$ の基盤露頭波の特性につ いて考察した．得られた結論は以下のようにまとめられる.

1) 提案手法により求めた地震計埋設深度間のフーリエスペクトル比 および各深度の加速度時刻歴波形は, 本震・余震とも，観測記録の 特徵をよく説明できる.このことは, 推定された地盤各層の等価 $\mathrm{S}$ 波速度および減衰定数のせん断ひずみ依存性, 基盤露頭波が, ある 程度の精度を有することを示唆している.

2) 余震記録の逆解析から推定された最大せん断ひずみは, 深度 $70 \mathrm{~m}$ までの砂層で $3 \times 10^{-5}-3 \times 10^{-4}$ 程度, それ以深で $1 \times 10^{-5}-2 \times 10^{-5}$ 程

\section{参考文献}

1) 気象庁:「平成 19 年（2007 年）新潟県中越沖地震」について（第 3 報）, http://www.jma.go.jp/jma/press/0707/16c/kaisetsu200707161600.pdf, (参照 200708-05).

2) 東京電力株式会社: 柏崎刚羽原子力発電所における平成 19 年新潟県中越沖 地震時に取得された強震観測データの分析に係る報告（第一報）, 2007.

3) 東京電力株式会社：柏崎刈羽原子力発電所における「平成 19 年 (2007 年) 新潟県中越沖地震」の加速度時刻歴波形デー夕 (本震, 余震), (財) 震災予 防協会, 2007.

4) 太田裕：地震工学への最適化法の適用, 1. 八戸港湾 SMAC 設置点の地下構 造推定, 日本建築学会論文報告集, No. 229, pp. 35-41, 1975. 
5) Schnabel, P. B., J. Lysmer, and H. B. Seed: SHAKE - A Computer Program for Earthquake Response Analysis of Horizontally Layered Sites, EERC Report, No. 72-12, 1972.

6) 小林喜久二, 久家英夫, 植竹富一, 真下貢, 小林啓美 : 伝達関数の多地点同 時逆解析による地盤減衰の推定, (その3) Q 值の基本式に関する検討, 日本 建築学会大会学術講演梗概集, 構造 II, pp. 253-254, 1999.

7）佐藤智美：鉛直アレーデータに基づく $\mathrm{S}$ 波の斜め入射を考慮した地盤の減 衰定数の同定 -焼き鈍し法の適用-, 日本建築学会構造系論文集, No. 569, pp. 37-45, 2003.

8) Chang, C. Y., M. S. Power, Y. K. Tang, and C. M. Mok: Evidence of Nonlinear Soil Response during a Moderate Earthquake, Proc., 12th Int'l Conf. of Soil Mechanics and Foundation Engineering, pp. 1927-1930, 1989.

9) 佐藤智美, 佐藤俊明, 川瀬博 : 堆積盆地における $\mathrm{S}$ 波伝播の識別と土の非線 形性の同定 - 足柄平野久野地区の鉛直アレーで観測された弱震動と強震動 の分析-, 日本建築学会構造系論文報告集, No. 449, pp. 55-68, 1993.

10) 杉戸真太, 合田尚義, 増田民夫 : 周波数依存性を考慮した等価ひずみによる 地盤の地震応答解析法に関する一考察, 土木学会論文集, No. 493/II-27, pp. 49-58, 1994.
11) Tokimatsu, K., and T. Sekiguchi: Effects of Nonlinear Properties of Surface Soils on Strong Ground Motions Recorded in Ojiya during the 2004 Mid Niigata Prefecture Earthquake, Soils and Foundations, Vol. 46, No. 6, pp.765- 775, 2006.

12) 木下繁夫 : 格子型フィルタの地震観測一の応用, 地震 2 , Vol. 39, No. 1, pp. 1-14, 1986.

13) Hardin, B. O., and V. P. Drnevich: Shear Modulus and Damping in Soils: Design Equations and Curves, Proc., ASCE, SM7, pp. 667-692, 1972.

14) Goldberg, D. E.: Genetic Algorithms in Search, Optimization and Machine Learning, Addison-Wesley Publishing Company, Inc., 412pp., 1989.

15) 山中浩明, 石田寛: 遺伝的アルゴリズムによる位相速度の逆解析, 日本建築 学会構造系論文集, No. 468, pp. 9-17, 1995.

16) 日本建築学会 : 入門 - 建物と地盤との動的相互作用,pp. 236-260, 1996.

17) Kokusho, T.: Cyclic Triaxial Test of Dynamic Soil Properties for Wide Strain Range, Soils and Foundations, Vol. 20, No. 2, pp. 45-60, 1980.

18）日本建築学会 : 建築物荷重指針・同解説, pp. 406-409, 1997. 